Maurer School of Law: Indiana University

Digital Repository @ Maurer Law

2006

\title{
Internationalizing U.S. Legal Education: A Report on the Education of Transnational Lawyers
}

Carole Silver

Indiana University Maurer School of Law, c-silver@law.northwestern.edu

Follow this and additional works at: https://www.repository.law.indiana.edu/facpub

Part of the Legal Education Commons, and the Legal Profession Commons

\section{Recommended Citation}

Silver, Carole, "Internationalizing U.S. Legal Education: A Report on the Education of Transnational Lawyers" (2006). Articles by Maurer Faculty. 321.

https://www.repository.law.indiana.edu/facpub/321

This Article is brought to you for free and open access by the Faculty Scholarship at Digital Repository @ Maurer Law. It has been accepted for inclusion in Articles by Maurer Faculty by an authorized administrator of Digital Repository @ Maurer Law. For more information, please contact rvaughan@indiana.edu. 


\title{
INTERNATIONALIZING U.S. \\ LEGAL EDUCATION: A REPORT ON THE EDUCATION OF TRANSNATIONAL LAWYERS
}

\author{
Carole Silver*
}

\begin{abstract}
This Article analyzes the role of U.S. law schools in educating foreign law graduates and the increasingly competitive global market for graduate legal education. U.S. law schools have been at the forefront of this competition, but little has been reported about their graduate programs. This Article presents original research on the programs and their students, drawn from interviews with directors of graduate programs at thirty five U.S. law schools, information available on law school web sites about the programs, and interviews with graduates of U.S. graduate programs. Finally, the Article considers the responses of U.S. law schools to new competition from foreign universities for the job of educating the world's lawyers.
\end{abstract}

\section{INTRODUCTION}

U.S. legal education reflects the essentially local character of law: students in U.S. law schools spend most of their time studying U.S. federal and state court cases, statutes, regulations, and the policies underlying them. And despite claims that globalization is leading to unified legal standards, much of law remains uniquely local, embodying local customs, legitimizing local moral judgments, and enforced, adopted and interpreted by legislators and judges who are selected directly or indirectly by the residents they will govern. Nevertheless, increasing numbers of lawyers originally educated outside of the U.S., whose work is centered outside of the U.S., are enrolling in U.S. law schools for graduate legal education.

* Senior Lecturer, Northwestern University School of Law. The information presented in this Article was presented at the 2004 AALS meeting for the Section of Graduate Legal Education in Atlanta. I am deeply grateful to the graduate directors, faculty, and graduates of LL.M. programs who so generously shared their time and experiences with me. Many thanks also to Francisco Javier Aguilar Noble, LL.M. 2003 Northwestern University School of Law, for excellent and thorough research assistance, and to Mary Daly, Nicole De Bruin, John O'Hare and Oscar Stephens for valuable comments on earlier drafts. 
Most of these lawyers are practitioners whose interest in U.S. law is pragmatic rather than academic. Given the law's local nature, this interest might be surprising. This Article takes this phenomenon as its starting point in examining U.S. law school graduate programs for foreign law graduates. ${ }^{1}$

U.S. graduate programs serve several functions in the development of careers of transnational lawyers. They provide an important link in the professional networks of transnational lawyers; they offer graduates credibility (including important experience in legal and business English) that enables them to connect with elite national and international law firms and raise their status in their home country legal professions; and they equip graduates with a legal terminology crucial for participation in the international legal services market.

But what benefit do U.S. law schools gain from offering graduate programs for foreign law graduates? And how did they become leaders in the business of global legal education? Section I of this Article considers these issues in the context of the growth of the international market for legal services. Section II presents basic data about the graduate programs for foreign law graduates offered by U.S. law schools. This data previously has not been available, perhaps because the American Bar Association, the traditional repository of information about U.S. legal education, does not directly regulate the graduate programs; rather, it "acquiesces" in the existence of the programs. The absence of regulation corresponds to an absence of data in this instance: schools are not required to disclose details about their graduate programs and in most cases they are reluctant to do so. Section II is based on information about the graduate programs gathered from law school web sites $^{2}$ and supplemented by detailed information provided by the

1 Graduate programs include a one-year degree, including the LL.M., whether general or specialized in focus, MCL (masters of comparative law), MCS (masters of comparative studies), and MALS (masters of American legal studies). All of these are included in this study. A doctorate in law (SJ.D. or JSD) is outside the focus of the Article.

2 The 102 schools listed in Table 1, infra, offer 189 graduate programs available to foreign law graduates. The particular programs seem to be quite fluid - what is described on a website may not correspond to the description of programs in a brochure that was printed a year earlier. This Article relies on web sites to provide the most accurate and recent information, based on the assumption that web sites are the most likely source of information for foreign law graduates contemplating application to U.S. law schools and the resulting incentive to keep web site program descriptions current. 
directors of graduate programs at thirty-five law schools. ${ }^{3}$ Section III combines this law school data with the perspective of students in U.S. graduate programs to present a broader account of the role of graduate students and programs in U.S. legal education. Finally, Section IV considers the increasing competition in the graduate legal education market and the challenges facing U.S. law schools.

\section{Contextualizing the Growth of the Market for Graduate Legal Education in the U.S.}

U.S. law schools long have attracted foreign law graduates pursuing academic careers. Studying in the U.S. was a prerequisite to securing an academic appointment in many countries and U.S. graduate programs were supportive of this academic approach: earlier generations of graduate programs were focused on the production of a thesis that would be particularly useful to a career in the academy. After graduation most scholars returned to their home countries, as they had intended when they initially enrolled. The U.S. law school experience was a credential valued in their home countries and the experience of studying in the U.S. did not sway them from their original career plans.

The global political and economic changes that occurred in the 1980s and 1990s explain much about the shift in the focus of graduate law programs from scholars to practitioners. This was a period of tremendous change on the international scene. The financial markets witnessed the development of an international derivatives market based upon the earlier market for swaps, which brought investment bankers and lawyers together in a contest for innovation. ${ }^{4}$ The fall of the Berlin Wall in 1989 opened new markets, and the reduced role of the state in national economies required private resources to assume increasing significance. By the early 1990 s, cross-border investments were supporting the development of international capital markets and transnational investment was booming. ${ }^{5}$ Lawyers helped to finance these political and economic changes. U.S. law firms expanded internationally during this period by opening foreign offices and increasingly representing for-

3 The detailed information was gathered in late 2003 through conversations and emails.

4 On the development of the derivatives market, see Schuyler K. Henderson, Regulation of Swaps and Derivatives: How and Why, 8 J. INT'L BANKING L. 349 (1993).

5 See generally, J. William Hicks, International Dimensions of U.S. Securities LaW ch. 3 (Nicola Padfield ed., 2005). 
eign governments and private enterprises. ${ }^{6}$ They competed fiercely in European capitals and, where local regulation permitted, in Asia as well. In 1998, when the American Lawyer published its first "Global Fifty" list of law firms ranked by size and revenue, U.S. firms occupied thirty slots of the fifty largest firms internationally, and all but seven of the top fifty ranked by revenues. ${ }^{7}$

The prominence of U.S. law firms in the international legal market supported the developing interest of foreign law graduates in U.S. legal education. Equally important, U.S. lawyers increasingly represented foreign corporations and governments in their quest for financing. Further, U.S. corporations were expanding globally as well, needing local representation in addition to the services offered by their U.S. counsel. In order to represent U.S. businesses and to participate in the growing market for international advice, foreign lawyers perceived that they needed to be able to speak the same language as U.S. lawyers, both literally and conceptually.

\section{Graduate Programs for Transnational Lawyers:} The DATA

The number of transnational lawyers attending U.S. graduate legal education programs has increased over the last decade or so, as has the number of graduate programs offered by U.S. law schools. This part of the Article examines the who, what and where of the graduate law phenomenon.

Graduate programs offered by 102 U.S. law schools are open to foreign law graduates. One-third of the schools offering these programs are public institutions; all 102 schools are listed in Table 1. The graduate programs available to foreign law graduates comprise only approximately fifty-five percent of all graduate programs offered by U.S. law schools; that is, there are nearly as many graduate programs only for U.S. lawyers (J.D. graduates) offered by U.S. law schools as there are programs for foreign law graduates. ${ }^{8}$

6 See Carole Silver, Globalization and the U.S. Market in Legal Services - Shifting Identities, 31 J. L. \& POL'y INT'L BUs. 1093 (2000).

7 John E. Morris, The Global 50, AM. LAw., Nov. 1998, at 45.

8 See the ABA's list of post-J.D. programs at http://www.abanet.org/legaled/postJ.D. programs/postJ.D.-school.html. In addition to the variety of LL.M. programs offered by U.S. law schools, just over thirty schools offer SJ.D. programs. SJ.D. programs typically require between one to three years in residence and completion of a thesis. 


\section{Table 1: Schools with LL.M. Programs in which Foreign LAWYERS MAY ENROLL}

1. Alabama, U. of

2. Albany Law School

3. American U.

4. Arizona, U. of

5. Arkansas, U. of

6. Baltimore, U. of

7. Boston U.

8. Brigham Young U.

9. California Western

10. California-Berkeley

11. California-Davis

12. California-Hastings

13. California-Los Angeles (UCLA)

14. Capital U.

15. Cardozo School of Law

16. Case Western Reserve U.

17. Chicago, U. of

18. Chicago-Kent

19. Cleveland State

20. Columbia U.

21. Connecticut, U. of

22. Cornell U.

23. Denver, U. of

24. DePaul University

25. Duke U.

26. Emory U.

27. Florida State U.

28. Florida, U. of

29. Fordham U.

30. Franklin Pierce Law Center

31. George Mason U.

32. George Washington

33. Georgetown

34. Georgia, U. of

35. Golden Gate U.

36. Hamline U.
37. Harvard

38. Hawaii, U. of

39. Hofstra U.

40. Houston, U. of

41. Howard U.

42. Illinois, $U$. of

43. Indiana U. (Bloomington)

44. Indiana U. (Indianapolis)

45. Iowa, U. of

46. John Marshall School of Law

47. Lewis and Clark College

48. Louisiana State U.

49. Loyola U. (Chicago)

50. Loyola Marymount University

51. Miami, U. of

52. Michigan State U., Detroit

53. Michigan, U. of

54. Minnesota, U. of

55. Missouri, U. of (Columbia)

56. Missouri, U. of (Kansas City)

57. New England School of Law

58. New York U.

59. Northwestern U.

60. Notre Dame, U. of

61. Pace U.

62. Pacific, U. of (McGeorge)

63. Pennsylvania State U.

64. Pennsylvania, U. of

65. Pepperdine U.

66. Pittsburgh, U. of

67. Saint Louis U.
68. San Diego, U. of

69. San Francisco, U. of

70. Santa Clara U.

71. Seattle U.

72. Southern California, U. of

73. Southern Methodist U.

74. St. John's U.

75. St. Mary's U.

76. St. Thomas U.

77. Stanford U.

78. Stetson. U.

79. Suffolk U.

80. SUNY Buffalo

81. Temple U.

82. Texas, U. of

83. Touro College

84. Tulane U.

85. Tulsa, U. of

86. Utah, U. of

87. Valparaiso U.

88. Vanderbilt U.

89. Vermont Law School

90. Villanova U.

91. Virginia, U. of

92. Wake Forest U.

93. Washington and Lee U.

94. Washington U. (St. Louis)

95. Washington, U. of

96. Wayne State U.

97. Whittier Law School

98. Widener U.

99. Willamette U.

100. William and Mary College

101. Wisconsin, U. of

102. Yale U.

The number of schools with graduate programs available to foreign law graduates increased more than fifty percent in the fiveyear period between 1998, when sixty-seven schools offered graduate programs in which foreign law graduates could and did enroll, and 2003. ${ }^{9}$

The schools offering graduate programs in which foreign law graduates may enroll are a diverse group in terms of their ranking in U.S. News \& World Report. These rankings are unrelated to the qualities of the graduate programs for foreign law graduates; the graduate programs themselves are not ranked (unless they are con-

91998 information is based upon comments made by J. Richard Hurt, then-Deputy Consultant on Legal Education for the ABA, as part of his presentation to the Conference on Post-J.D. Education for Foreign Lawyers held at Duke University School of Law (Spring 1999) (on file with author). 
sidered part of another category, such as tax, for example). Rankings are considered here only as one indication of a variety of the schools sponsoring the graduate programs. Forty-six percent of the Table 1 schools occupy a spot in the first tier of the U.S. News rankings. ${ }^{10}$ Figure 1 illustrates the U.S. News ranking of the 102 law schools offering graduate programs open to foreign law graduates.

\section{Figure 1: U.S. News Rankings for All LaW Schools With} LL.M. Programs Open to Foreign LaW Graduates

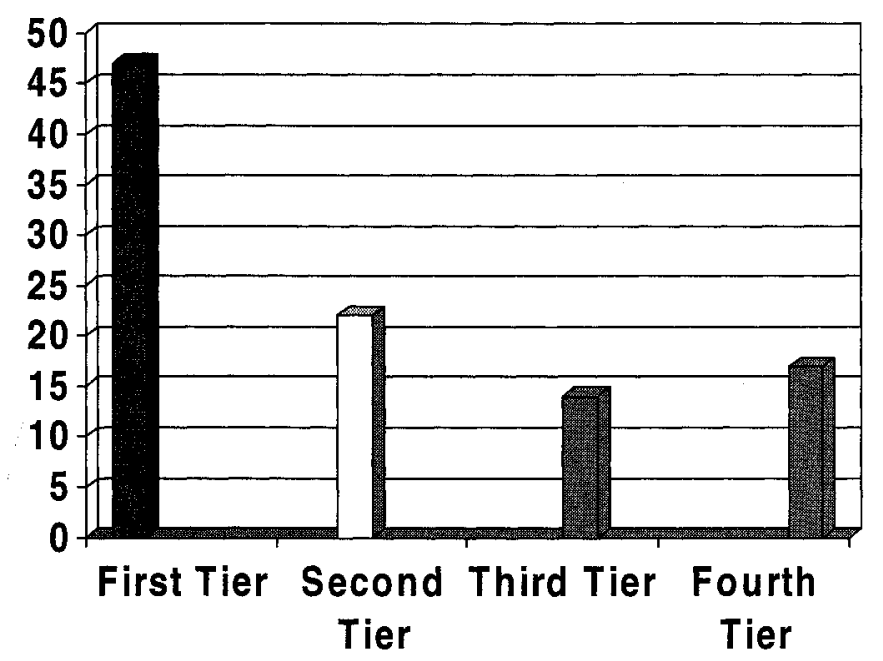

Figure 2 divides the 102 Table 1 schools offering graduate programs for foreign law graduates between public and private institutions for each of the U.S. News tiers. ${ }^{11}$

10 Based on 2003 law school rankings, there are forty seven schools with programs open to foreign law graduates in Tier 1, twenty four schools in Tier 2, fourteen schools in Tier 3, and seventeen schools in Tier 4. For current rankings, see Complete Guide to Law Schools: Rankings, available at http://www.usnews.com/usnews/edu/grad/rankings/law/law index_brief.php (last visited February 22, 2005).

11 Of the thirty-five schools that provided detailed information about their graduate programs for foreign law graduates, twenty-three ranked in the Tier 1 on the U.S. News 2003 ranking; eight schools ranked in Tier 2; and one each in Tiers 3 and 4. 
Figure 2: Distribution of Schools Offering Graduate Programs for Foreign Law Graduates Regarding U.S. NEWS \& WORLD REPORT RANKING
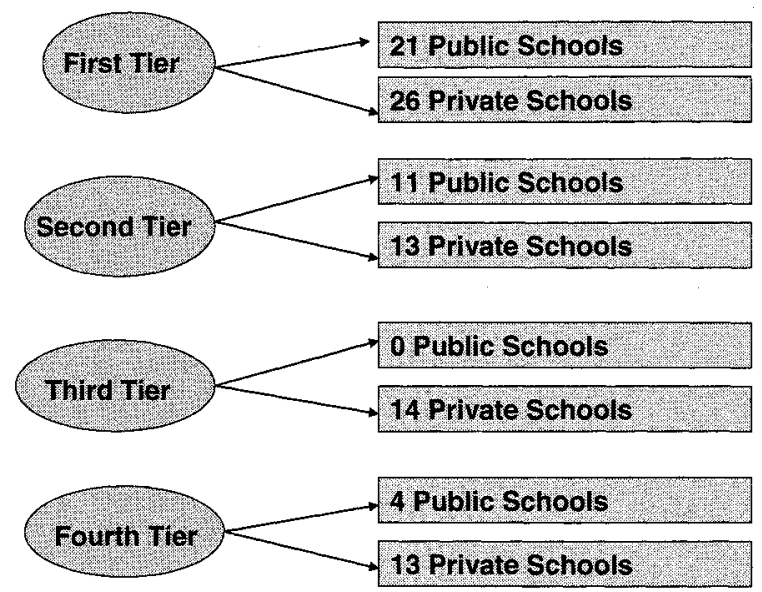

The number of lawyers enrolled in U.S. graduate law programs has increased at the same time as has the number of programs. In 1998, the sixty-seven schools with graduate programs open to foreign law graduates enrolled over 2000 foreign students, who comprised forty-four percent of the entire post-J.D. population. According to the ABA, in the five years ending in 2004, enrollment of foreign law graduates in post-J.D. programs in U.S. law schools has grown by more than $130 \% .{ }^{12}$ The ABA reported that ninety-six U.S. law schools enrolled a total of 4469 foreign law graduates in 2004. This rate of growth exceeds the fifty-four percent increase in the number of foreign-educated lawyers who sat for the New York bar exam during approximately the same period. ${ }^{13}$

12 Information on foreign law graduates enrollment in LL.M. programs was provided by the ABA and is on file with the author.

13 In 1998, 2047 lawyers who earned their legal education outside of the U.S. sat for the New York bar exam; in 2003, the most recent year for which data is available, this increased to 3151 foreign-educated individuals-an increase of approximately fifty-four percent in five years. See Nat'l Conf. Bar Examiners, Total Taking and Passing by SOURCE OF LEGAL EDUC. IN 1998, at 4 (1999), available at http://www.ncbex.org/stats/pdf/ 1998stats.pdf (last visited Jan. 25, 2005); NAT'L Conf. of Bar Examiners, Persons TakING ANd PAssing by Source of Legal Educ. in 2003, at 9 (2004), available at http:/ www.ncbex.org/stats/pdf/2003stats.pdf (last visited May 18, 2004). At least in New York, these numbers almost certainly include lawyers educated in a common law system outside of the U.S. who do not need to complete an LL.M. in order to sit for the bar. See, e.g., N.Y. Comp. Codes R. \& Regs. tit. 22, \& 520.6 (2005), available at http://www.nybarexam. org/court.htm (last visited Mar. 20, 2006). 
Graduate programs for foreign law graduates generally reported a deliberate increase in size beginning in the late 1990s; this increase occurred at a time when overall applications to J.D. programs were decreasing and may have been a response to this shift. ${ }^{14}$ For example, one school that has had a graduate program available to foreign law graduates for more than twenty years increased from approximately thirty-five students in 1990-91 to approximately eighty students in 2003. Another program that began in 1970 enrolled twenty students during the 1980s and 1990s, and increased over the 2001-03 period to approximately fifty students per year. A third program began in 1994 and grew from eleven students to a 2003 enrollment of forty to fifty students. A fourth program, created in 2002, enrolled ten students its first year and thirty in the second year. Although information about the size of graduate programs available to foreign law graduates generally is not disclosed on law school web sites, information about program size for the thirty-five schools that offered detailed information about their programs is as follows:

\section{Table 2: Size of One Year Graduate Programs, FOR 35 SURVEYEd SCHOOLS}

(M) indicates that the school has multiple one-year graduate programs in which foreign law graduates may enroll, and the number reported is the combined number of students in all such programs
1. 300 students $(\mathrm{M})$
2. 174 students (M)
3. 150 students
4. 125 students (M)
5. 127 students (M)
6. 82 students
7. 80 students
8. 79 students
9. 73 students
10. 72 students
11. 64 students
12. 55 students

13. 55 students

25. 20 students

14. 50 students

26. 15 students

15. 43 students

16. 37 students (M)

27. 15 students

17. 35 students

28. 12 students

18. 32 students

29. 11 students

19. 32 students

30. 7 students

20. 32 students

31. 5 students

21. 30 students

32. 5 students

33. 5 students

22. 28 students

23. 27 students

24. 21 students

34. 0 students

35. 0 students

The average number of students in the graduate programs at these thirty-five law schools for the 2003-04 academic year was approximately fifty-four students. ${ }^{15}$

Another factor relating to the variety of graduate law programs available to foreign-educated law graduates is their location

14 See Law School Admission Council, Volume Summary Data, http://www.lsac. org/LSAC.asp?url=LSac/LSAC-volume-summary.asp (last visited Oct. 4, 2005).

15 Two schools reported on brand new programs and had not yet enrolled students. 
in the U.S. The experience of students enrolled in a graduate program located in a major metropolitan area is different than that of students attending a rural school. Figure 3 illustrates the location of U.S. law schools offering LL.M. programs for foreign law graduates, coded for the number of schools in each state.

While certain U.S. law schools offer no graduate programs for foreign law graduates, others offer multiple such programs. ${ }^{16}$ In order to illustrate the number of programs available to foreign law graduates, as opposed to schools with such programs, Figure 4 uses the same coding system. ${ }^{17}$ The concentration of programs and schools in major commercial states is quite clear.

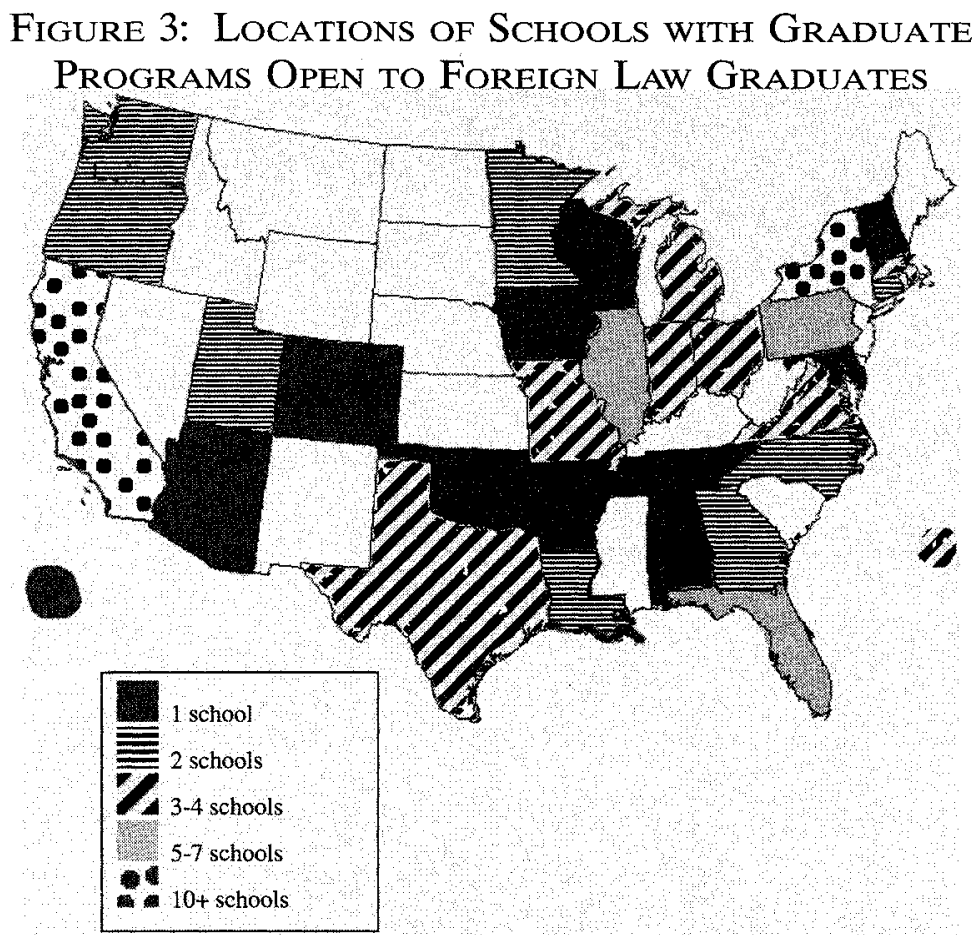

16 Using Northwestern as an example, albeit not necessarily representative of other schools, the general LL.M. program existed for decades and increased in size quite dramatically in the mid-1990s. In 1999, Northwestern began a new joint program in law and business, and in 2002 an LL.M. tax program - the latter is not aimed at foreign law graduates, but it has admitted at least one foreign law graduate. And in 2003, Northwestern began an executive LL.M. program for Korean lawyers that conducts classes in Seoul and in Chicago.

17 Please see the legend below Figure 3 and 4. Dark grey indicates one-two programs in the state, horizontal stripes indicates three-five programs, diagonal stripes indicates sixeight programs, light grey indicates ten-thirteen programs, and dots indicates more than twenty. 
Figure 4: Locations of Graduate Programs Open to Foreign LAW GRAdUATES

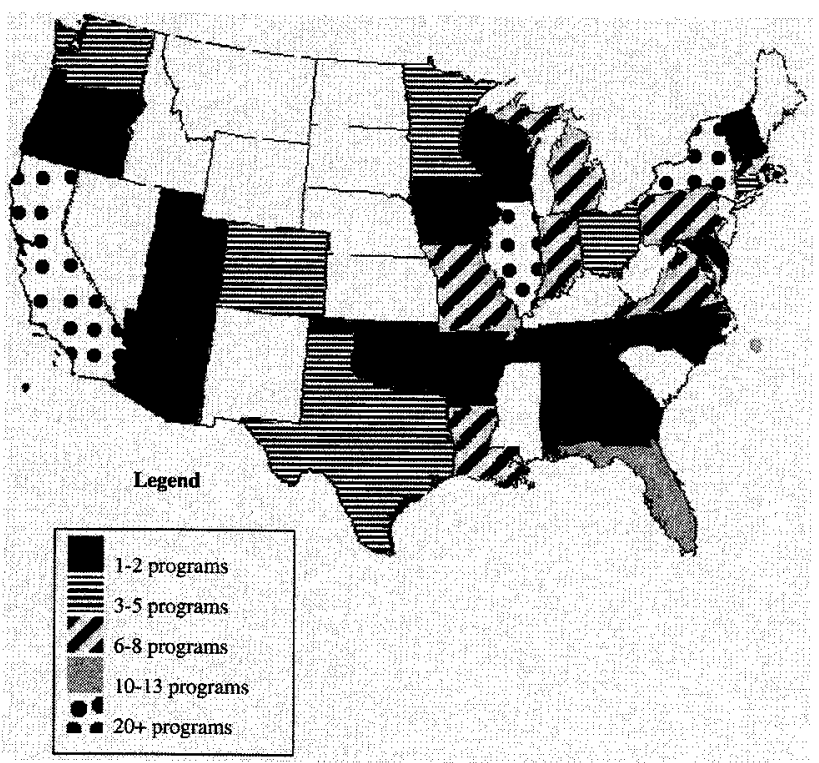

The break-down of programs per school is illustrated in Figure 5.18 Figure 5: Number of Programs per School

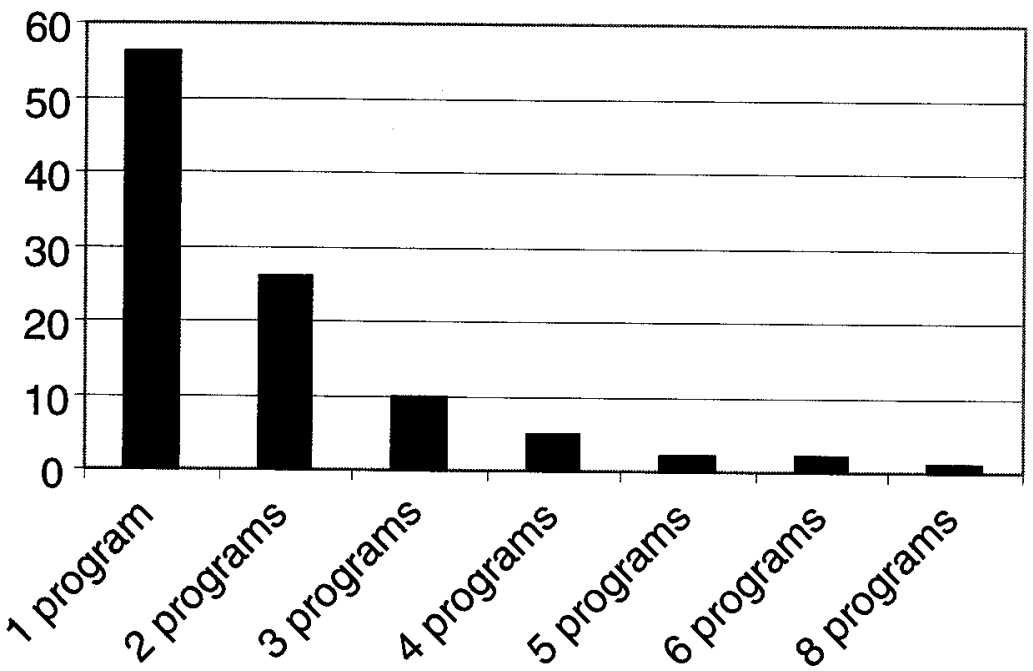

18 Of the 102 schools with programs available to foreign law graduates, web sites describe forty-six schools with multiple programs: twenty-six schools have two programs, ten schools have three programs, five schools have four programs, two schools have five programs and two have six programs, and one school has eight programs. This information was gathered from web site descriptions. . 
Programs also differ in their student populations. Certain graduate programs are open to foreign and domestic law graduates, while others are available exclusively to foreign law graduates. The distinction may be a matter of marketing the program or may relate to particular course requirements for the degree. It is not entirely clear how applicants weigh the merits of an exclusively foreign-student program. Fifty-eight schools, identified in Table 3, offer a total of sixty-six one-year graduate programs exclusively for foreign law graduates; at least four schools (indicated by ${ }^{*}$ ) offer multiple programs open only to foreign law graduates.

\section{Table 3: Schools Offering Programs Exclusively for Foreign LaW Graduates}

1. University of Alabama

2. Albany Law School

3. University of Baltimore

4. Boston University

5. Brigham Young University

6. California Western University

7. University of California-Hastings

8. UCLA

9. Case Western Reserve University

10. Chicago-Kent College of Law*

11. University of Connecticut

12. Cornell University

13. University of Denver

14. Duke University

15. Emory University

16. Florida State University

17. University of Florida

18. Georgetown University

19. Hamline University

20. University of Hawaii

21. Hofstra University

22. University of Houston

23. Howard University

24. University of Illinois

25. Indiana University-Indianapolis

26. John Marshall Law School

27. University of Miami

28. Michigan State University

29. University of Michigan
30. University of Minnesota

31. New England School of Law

32. New York University

33. Northwestern University*

34. Pace University

35. Pennsylvania State University (Dickinson)

36. University of Pittsburgh

37. St. Louis University

38. University of San Diego

39. University of San Francisco

40. University of Santa Clara*

41. University of Seattle

42. University of Southern California

43. Southern Methodist University

44. St. Mary's University

45. Stanford University*

46. Temple University

47. University of Texas

48. Touro College

49. University of Tulsa

50. Valparaiso University

51. Vanderbilt University

52. University of Virginia

53. Wake Forest University

54. Washington \& Lee University

55. Washington University in St. Louis

56. Whittier School of Law

57. College of William \& Mary

58. University of Wisconsin

It is possible to gain a sense of the development of LL.M. programs from the thirty-five schools that provided detailed information. Among these schools, more programs were created in the 1990 s than during any other period, followed by the current period from 2000 to the present. Figure 6 illustrates the starting date of 
LL.M. programs for foreign law graduates offered by these schools. ${ }^{19}$

Figure 6: When Were LL.M. Programs Created?

(Showing 42 programs of 35 schools)

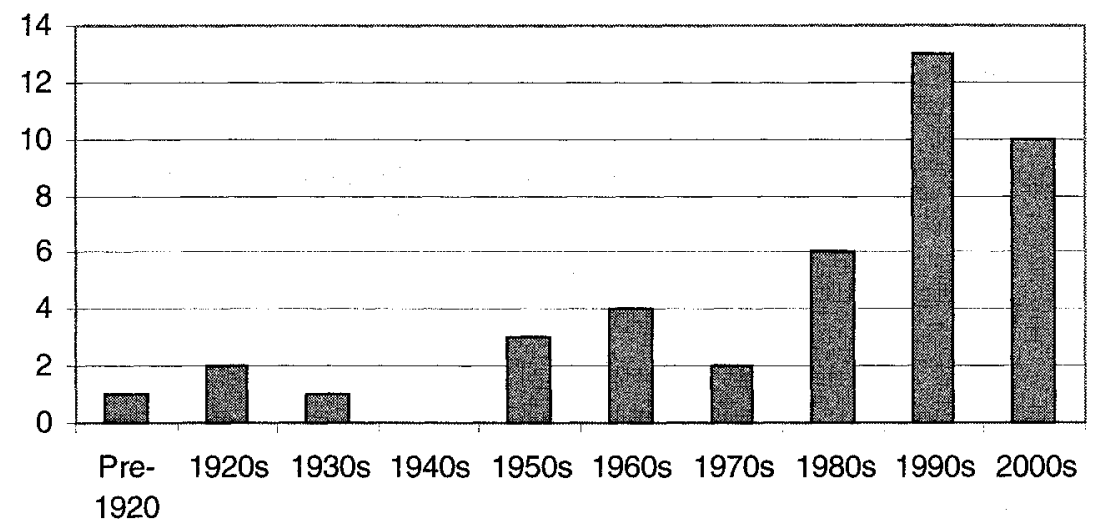

\section{ExPectations AND PAyoffs For the Schools AND} THE STUDENTS

The landscape of graduate programs available to foreign law graduates provides a starting point for understanding the development of the international legal education market. But what do U.S. law schools gain from hosting foreign law graduates in their graduate programs? And how do the graduate programs satisfy the needs of international students?

Law schools experience financial and reputational gains from their graduate programs for foreign law graduates. These programs internationalize the student bodies of law schools, which schools use as evidence of their international and even global characters. While the international character of a law school may stem from its LL.M. program, the significance of the international label addresses a law school's ability to attract applicants for its J.D. program as well. As one graduate program director explained, the LL.M program brings "the global perspective to our students" 20 meaning their J.D. students. Similarly, the University of Baltimore School of Law describes its LL.M. program as providing the opportunity "to give foreign lawyers a first-rate education in the laws of

19 A number of programs at the thirty-five schools are not included in Figure 5 because of an absence of information.

20 Response of graduate director at school \#2 to survey. 
the U.S. and to broaden the experience of all law students through more interaction with international students and exposure to diverse populations." 21

Most LL.M. programs are built around foreign students taking a majority of their courses with J.D. students, guaranteeing at least a minimal level of academic interaction between the two groups; occasionally LL.M. students offer their home country perspective on topics examined in class and bring a comparative substantive insight to J.D. students. Graduate programs that attract foreign students allow U.S. law schools to legitimize their claims to being international, and this international label is crucial to law schools as they try to compete for J.D. applicants; it indicates a school's forward-looking approach and its ability to educate students for the future.

A second benefit of graduate programs for foreign law graduates relates to money: these programs are a significant source of revenue. Graduate programs are not subjected to the same strict oversight by the ABA as J.D. programs and this may enable law schools to focus more on cost efficiencies than is possible for the J.D. programs. ${ }^{22}$ Law schools tend to thinly-staff the graduate programs in terms of both faculty and administrative support, so that most of the tuition dollars paid by international students in the LL.M. programs are supported by costs already incurred in connection with the J.D. programs. ${ }^{23}$ Perhaps equally important, this tuition income comes without any concern regarding the impact on a law school's U.S. News ranking relating to the credentials of students admitted to the graduate program. Foreign graduate students do not submit LSAT scores and are not included in a law school's statistics for purposes of the U.S. News ranking.

21 UNIVERSITY OF BALTIMORE, SCHOOL OF LAW, http:/law.ubalt.edu/academics/concentrations/llm.html (last visited December 26, 2003) (emphasis added).

22 According to the survey responses from the graduate program director at one U.S. law school ("law school \#1"), the LL.M. program allows them to "internationalize [their] school of law, ... to raise [their] law school's visibility abroad, and to earn revenue ...." See Responses to survey from director of graduate programs for law school \#1 (on file with author).

23 According to the detailed information provided by thirty-five law schools, administrative staffing of LL.M. programs typically is minimal. The average number of staff supporting the LL.M. programs at the thirty-five surveyed schools was two persons, excluding faculty, admissions and career placement personnel. Three programs are directed by faculty without support from administrative staff; eight schools also have all or some of an admissions position allocated to the program and two schools have a career placement position allocated to the program. 
The interests of law schools in hosting graduate programs for foreign law graduates are quite different than the interests of the graduate students in these programs. As described in Section I, the typical student in graduate programs today is a practitioner rather than a scholar. Generally, the U.S. law degree serves as a common currency for foreign law graduates. One LL.M. graduate explained that "for a foreigner to have something as a point of reference for others who can understand, as a degree from a prestigious school is, is a very important asset." ${ }^{24}$ Another graduate was more direct. He explained that the "value of law school [in the U.S.] is [the] prestige of [the] law school. It convinces clients of credibility. They say, 'Oh, you graduated from Harvard, you can have this business.'"25

However, what exactly is it about the U.S. law school experience that offers value for foreign law graduates? For many, the importance of U.S. clients in their home countries convinces them of the need to acquire a U.S. law experience and the skills that go along with it. Learning English, particularly legal English, is crucial, as is having some exposure to U.S. culture. Foreign lawyers from diverse countries - including countries in Latin America, Europe, and Asia - report that at least half of the work in their home country is performed in English. One recent graduate explained, "Doing an LL.M. guarantees that you know how to speak English, that you've been exposed to American culture, legal culture. This makes [the clients] feel more comfortable."26 Another explained,

One main reason [I'm] here is to practice ... English. . . . That's important because $70 \%$ of clients are U.S. based companies. The better deals involve international parties. If you want to be on these deals, you must be able to speak, read, write in English as if it's your own language; [this is] almost mandatory. Most law firms require knowledge of English before hiring in a job as a lawyer. ${ }^{27}$

The same lawyer commented, "The law component is an excuse to practice English and to be comfortable with the U.S. culture and in English." 28 Another recent graduate explained the importance of being fluent in legal English:

24 Interview with "graduate student \#10," (November 2003).

25 Interview with "graduate student \#5," (November 2003).

26 Interview with "graduate student \#1," (November 2003).

27 Interview with "graduate student \#4," (November 2003).

28 Int. 4 (November 2003). 
I work in English half of the time.... [E]ven if ...both sides are ... lawyers [from my home country], ... you [might] look forward to an IPO which is in the U.S. We try to keep all the documents in English in order to preserve it for the future. So even if both parties are [from my home country], ... the documents are going to be in English .... There is always someone who doesn't speak [my language] for some reason. But the documents are in English. ${ }^{29}$

Another lawyer explained, "Most clients are foreign, and we often have to deal with legal counsel, too. The U.S. is where most foreign investment comes from. I want to become acquainted with the U.S. legal system, with the way lawyers and clients think and what they think about when deciding to do business in [my home country]." 30

If foreign law graduates want to learn English and soak up U.S. culture during the LL.M. year, graduate programs are equally intent upon their foreign students having sufficient grounding in English to succeed. Assessment of language ability is a crucial part of the admissions decision for law schools. Nearly every school states on its website that it requires the TOEFL exam, and most schools have established a minimum TOEFL score requirement equal to 600 out of 677 (for paper-based version) or 250 out of 300 (for computer-based version). ${ }^{31}$ Schools may require higher scores for programs open to both foreign and domestic lawyers. ${ }^{32}$

A number of the thirty-five schools that provided detailed information indicated that they supplement TOEFL information with personal conversations to help assess applicants' English ability. For some of these schools, the TOEFL requirement as indicated on the school's web site is lower than 600, presumably

29 Int. 6 (November 2003).

30 Int. 9 (March 1999).

31 There are some exceptions to this - the range indicated on web sites is between a low of 550 ( 213 for the computer-based exam) and a high of 650 . In addition, a new internetbased test and scoring system has been introduced; see http://www.ets.org/portal/site/ets/ menuitem.1488512ecfd5b8849a77b13bc3921509/?vgnextoid=E9772d3631df4010VgVCM1 0000022f95190RCRD\&vgnextchannel=4e0bd898c84f4010 VgnVCM10000022f95190RCRD \#internet_based_test.

32 For example, on its website, the University of Wisconsin states that the TOEFL score required for its Masters in Legal Institutions (MLI) program, which is designed exclusively for foreign law graduates, is 600 (250 on the computer-based exam) http://www.law.wisc. edu/grad/mli.htm (last visited March 16, 2006); in contrast, Wisconsin's LL.M. program, open to both foreign and U.S. lawyers, is described on the website as requiring a TOEFL score of 625 (263 on the computer-based exam), http://www.law.wisc.edu/grad/LLMreqs. htm (last visited March 16, 2006). 
because of the supplementary information. In addition to telephone conversations with applicants, most admission officers look for work experience, and one indicated that he specifically is interested in evidence that an applicant has worked in an English-language environment. ${ }^{33}$

Another reason that students from particular jurisdictions enroll in U.S. graduate law programs is to bypass restrictions on professional qualification. In Japan and Korea, for example, the very low bar passage rate means that most law graduates do not pass the bar exam. For students from these countries who have not passed their domestic bar exam, coming to the U.S. to study enables them to sit for the bar in certain U.S. jurisdictions; notably, New York. If they pass the New York bar, they can return to their home countries with an important credential - that of the foreign lawyer. Moreover, Japanese and Korean students who have passed the bar in their home countries are no less intent upon passing a bar exam in the U.S.; for them, too, the credential is all-important. According to one recent graduate, "In Korea, [the] LL.M. value is first [the] American license - [the] bar exam. [The] LL.M. is a process to get [a] license." 34

Personal experiences also play a role in motivating individuals to enroll in U.S. graduate law programs. Certain students had lived in the U.S. previously and want to return, or want to have time away from home with a new spouse or to break away from the routine of practicing law in their home country. ${ }^{35}$ Personal interests are never far from the professional.

\section{A. The Competition between U.S. Law Graduate Programs}

U.S. law schools compete for foreign graduate students on a variety of criteria. According to graduates of LL.M. programs interviewed for this Article, selection of a particular U.S. law school graduate program is influenced most often by the following factors (in no particular order): the U.S. News ranking of the law school, a particular characteristic or focus of the graduate program at certain

33 In fact, this need to prove proficiency in English is one reason that a foreign law graduate might accept a position with an American or British law firm, even if the position is low-paying or low-status, or both; the connection with the firm gives credibility to the claim of English proficiency, which in turn is beneficial in the application process.

34 Int. 5.

35 Int. 17, 13, 20. 
law schools, funding by the law school, and knowledge of someone with a connection to the school or its location.

Graduates of U.S. law programs regularly mention the U.S. News ranking of a school as one consideration in applying to a particular school or choosing one school over another. According to one faculty member at a well-known U.S. law school, "the less [foreign law graduates] know about the U.S., the bigger snobs they are about schools' names." ${ }^{36}$ The importance assumed by the U.S. News ranking changes, of course, depending upon whether the foreign law graduate attended a school with a very high U.S. News ranking or one with a lower ranking. Graduates of schools with U.S. News rankings in approximately the top twenty consistently referred to the ranking of their alma mater as significant in their decision to apply to and enroll in a particular school. For these students, the value of the LL.M. is linked to the status of the law school; it makes no difference that the U.S. News rankings are based upon assessment of J.D. programs. ${ }^{37}$

Certain LL.M. programs have distinctive characteristics that attract applicants. One example is the opportunity to work in an internship during or following the LL.M. course work. ${ }^{38}$ This was

36 Faculty interview 29 (March 2006).

37 One ranking of U.S. LL.M. programs is offered by American Universities Admission Program, at http://www.auap.com/llm.html (last visited October 5, 2005). According to the website, rankings are based on the following criteria: "This classification is based on the program quality, admissions rate, world image of the university, average starting salary and satisfaction index of international students. This classification is global and does not reflect the comparative strength of each program in a specific field of Law (such as International Civil Law, Taxation, Internet, intellectual property etc.)[.]" Id. Objective data and qualitative methodology related to the production of this ranking are not provided. Graduates interviewed for this article did not mention this ranking in their interviews.

An alternative source of information about LL.M. programs, including programs offered by non-US law schools, is LL.M. Guide 2001-2006, Pritzwalks Ltd., (available at www.llmguide.com).

38 See e.g., Internships Provide Practical Education for LL.M. Grads, in 9 UNIVERSITY of Pittsburgh Center for International Legal Education Notes 4 (Fall 2004) ("One of the unique aspects of the LL.M. Program for Foreign Law Graduates at the School of Law is that it offers each student the opportunity of an internship during the summer following graduation. ... In recent years, students have participated in internships with top regional and international law firms and corporations in Chicago, Pittsburgh, New York, and Washington, D.C., with federal and state judges, and in government offices."), http://www.law.pitt.edu/academics/docs/CILEnotes2004.pdf (last visited March 16, 2006); Case Western Reserve University's LL.M. program, at http://www.law.case.edu/curriculum/ $1 \mathrm{~mm} /$ content.asp?id=367. (last visited March, 9, 2005) ("For interested LL.M. students, the law school arranges internships the summer following the program with law firms, corporations, and courts for students who want to see how law is practiced in the U.S. Cleveland's position as a corporate and legal center provides many internship options."). University of 
cited as crucial by a student who wanted the LL.M. degree but also wanted to spend time putting course work into practice. ${ }^{39}$ Another way that law schools try to distinguish themselves is by adopting a particular substantive focus to their graduate programs. While certain programs allow students to study nearly any topic addressed in law school,,$^{40}$ others are focused on a particular substantive area of law that may correspond to direction on the courses students must take. If U.S. or American law is considered a substantive specialty, then approximately seventy-five percent of the programs in which foreign law graduates may enroll have a substantive focus. On the other hand, eliminating a category for U.S. and American legal studies on the ground that these are actually general programs ${ }^{41}$ leaves approximately sixty-five percent of LL.M. programs available to foreign law graduates with a special substantive focus.

LL.M. programs with a substantive law focus are aimed at twenty-three substantive law specializations, including U.S. law. This includes twenty-eight programs that identify themselves as having a focus on international and comparative law, and twenty with a focus on U.S. law. Other areas of substantive focus are listed below in Table 4, with the number of programs in that area indicated next to the specialization:

the Pacific, McGeorge School of Law, also offers an LL.M. with an internship component; see http://www.mcgeorge.edu/international/transnational_business/llm_with_internship. htm (last visited Oct. 5, 2005).

39 Int. 20.

40 The qualification about focus of study relates to curricular requirements that may impede a substantive focus, and the prohibition on first-year courses found at several schools.

41 It is not clear whether it is appropriate to count the U.S.-focused programs as having a substantive focus, since these programs may be general in their approach and use the title U.S. or American law as a way to identify their attraction to foreign law graduates. 


\section{Table 4: LL.M. Programs with Topical Focus}

Topic

Number of

INTERNATIONAL LAW, COMPARATIVE LAW ${ }^{42}$

Programs

TAX, INTERNATIONAL TAX ${ }^{43}$

U.S. LAW, AMERICAN LAW

BUSINESS, CORPORATE LAW, FINANCIAL SERVICES, BANKING $^{45}$

INTELLECTUAL PROPERTY, INTERNATIONAL IP ${ }^{46}$

ENERGY, ENVIRONMENTAL LAW ${ }^{47}$

DISPUTE RESOLUTION

HEALTH LAW

INTERNATIONAL TRADE ${ }^{48}$

GOVERNMENT PROCUREMENT, INTERNATIONAL GOVERNMENT PROCUREMENT, LAW \& GOVERNMENT

INTERNATIONAL HUMAN RIGHTS

AMERICAN INDIAN/INDIGENOUS PEOPLES LAW \& POLICY

LABOR \& EMPLOYMENT

ADMIRALTY

AGRICULTURAL LAW

CHILD \& FAMILY LAW

CRIMINAL LAW

EMPLOYEE BENEFITS

INSURANCE LAW

LAW \& ECONOMICS

PUBLIC SERVICE LAW

REAL PROPERTY \& DEVELOPMENT

SUSTAINABLE INTERNATIONAL DEVELOPMENT

Of the sixty-six programs available exclusively to foreign law graduates, ${ }^{49}$ twenty-six are general programs, nineteen are focused on U.S. law, thirteen on international or comparative law, ${ }^{50}$ two each on business and tax, and one each on alternative dispute resolution, human rights and intellectual property.

42 Includes programs in international transactions and comparative law, American and comparative law.

43 Includes programs in business \& tax, and estate planning.

44 Nineteen schools have LLM programs focused on tax or international tax, and eighteen of these are at schools with more than one program: four schools with tax LLM programs have one additional LLM program; six schools have two additional LLM programs; four schools have three additional LLM programs; two schools have four additional LLM programs, one school has five additional LLM programs, and one school has six additional LLM programs.

45 Includes programs on corporate governance, securities, financial regulation, and bankruptcy.

46 Includes programs in law, science \& technology.

47 Includes programs in natural resources law and water resources.

48 Includes programs in international business and trade.

49 For a list of these sixty-six programs, see Table 3, supra.

50 This includes one program offered substantially in one particular foreign country and available only to lawyers in and of that country. 
Figure 7: Topical Focus of Programs Exclusively for Foreign LaW Graduates

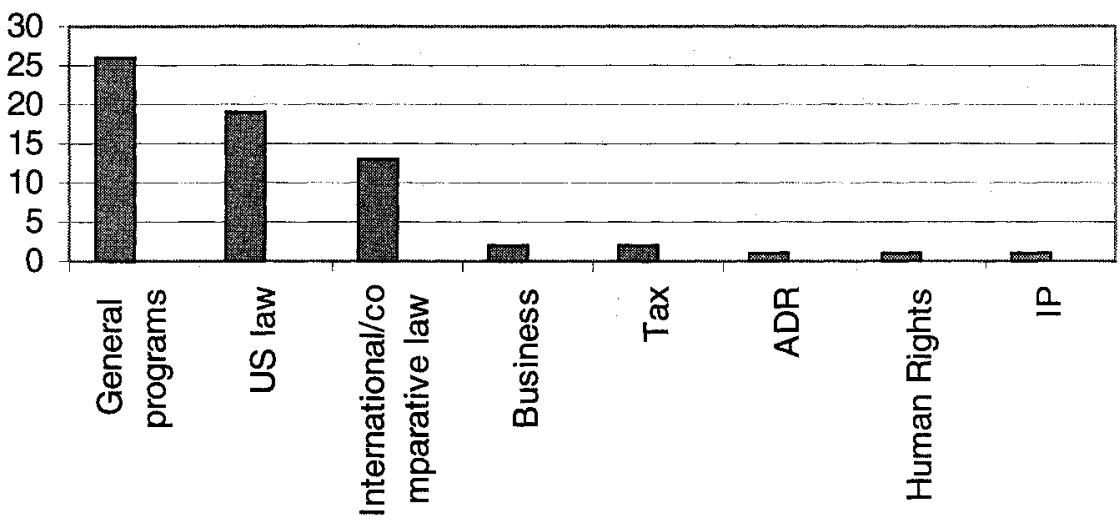

The percentage of substantively focused programs in the two groups - those programs open exclusively to foreign law graduates and those open to foreign and domestic students - compare as follows:

Table 5: Percentage of Substantively Focused Programs in Programs Exclusively for Foreign Law Graduates and Open to Foreign and Domestic Law Graduates

Exclusively Foreign Non-exclusive

General Programs

$\begin{array}{ll}39 \% & 25 \% \\ 11 \% & 29 \% \\ 15 \% & 20 \%\end{array}$

U.S. Law

$15 \%$

$20 \%$

Law

Apart from a substantive focus, graduate programs distinguish themselves on the basis of their curricula. There is quite a bit of variation in the substantive requirements of graduate programs available to foreign law graduates. One hundred and six programs impose some course requirement. As reflected in Figure 8, more than fifty programs require either an introductory course on the U.S. legal system or a course on legal research and writing. ${ }^{51}$ Another forty-five programs require students to take both of these courses. In addition, more than 120 programs impose some sort of writing requirement on students. This might take the form of a

51 Several of these programs excuse lawyers trained in common law systems from the requirement. 


\author{
thesis requirement, ${ }^{52}$ an independent research project, ${ }^{53}$ or a paper \\ in a seminar..$^{54}$
}

\title{
Figure 8: Form of Research/Written Work ReQuired by LL.M. Programs Open to Foreign Law Graduates
}

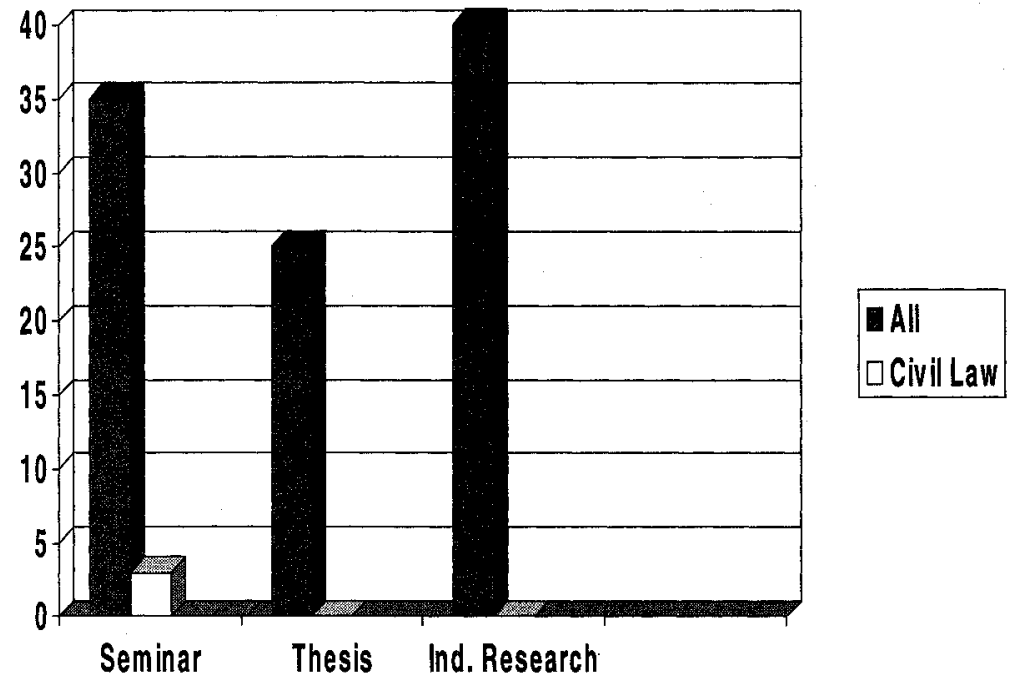

52 See, e.g., University of Georgia's LL.M. requirements, at http://www.law.uga.edu/ (last visited Dec. 29, 2003) ("Students must prepare a thesis on the subject described in their admissions application and confirmed at the time of enrollment."); Wake Forest University's program requires "Independent Research and Thesis, which offers two credit hours and should be completed during your year in residence. You can choose your thesis topic according to your own special interests. We will assign a professor who will serve as a mentor/advisor for the selection, research, and writing of your thesis . ..." http://www.law. wfu.edu/ (last visited Dec. 29, 2003).

53 See, e.g., the University of Texas LL.M. program requirements, at http://www.utexas. edu/law/ (last visited Dec. 29, 2003) ("Students enrolled in the LL.M. program must complete a minimum of twenty-four credit hours to obtain the LL.M. degree, and must also complete a substantial paper involving independent research and legal analysis").

54 See, e.g., the University of Michigan's requirements, at http://www.law.umich.edu/ (last visited Dec. 28, 2003) ("All master's degree students are required to complete a research paper in a seminar or as a supervised independent research project on a topic of their choice"). Students may choose between various forms of writing in approximately twenty-five programs. For example, Columbia University requires either two seminar papers or an independent research project ("All LL.M. candidates are required to include in their programs a writing project or projects that involve independent legal writing based on research, totaling four points of academic credit. The writing credits may be earned in conjunction with a seminar or through independent research with a faculty member. Two seminars requiring substantial papers satisfy this requirement, as does a four-credit research project, or any equivalent combination of undertakings."). See http://www.law.columbia.edu/ (last visited Dec.28, 2003). 
Finally, certain programs prohibit graduate students from enrolling in first-year courses. This was explained by one graduate director as being related to the assumption that students already have studied the basic subjects. ${ }^{55}$ Even so, another motivation for this prohibition is to preserve both the size and tenor of the firstyear courses.

The financial support available to foreign students is another important consideration in selecting a U.S. law school. Twentyfour of the thirty-five schools that provided detailed information offer some funding for graduate students. There is a wide variety of available resources; schools generally offer only partial funding to any student, and fund as few as two percent to as many as seventy percent of the foreign student population. Schools use the funding to either attract students from particular countries that otherwise would not be represented in the class, or to attract students who otherwise would enroll in graduate programs offered by competing U.S. law schools. Moreover, four schools reported that they provide no funding whatsoever to their graduate students.

Apart from support by the U.S. law schools, students are funded by employers as well as by their home country governments. According to graduate directors, employer funding is most common for students from Japan and Korea; employers pay for tuition and a living stipend during the academic year. Graduates from Japan and Korea explained that it also is common for their home country employers to pay their wages during a U.S. internship at an unrelated organization following graduation from the LL.M. program. ${ }^{56}$ Graduate directors report that government funding is more common for students from other countries, including Germany.

Finally, graduates rely on personal acquaintances for information about particular U.S. law schools and their locations. Knowing someone who has a connection to the law school gives some comfort to foreign applicants. It is not necessary for the foreign law graduate to have a close, personal connection to a person with experience in the U.S., and often graduates report that they knew of someone who had studied at a particular law school although

55 Faculty Int. \#29 (March 2006).

56 Int. 5, 7. See Part C.3, infra (regarding the use of home country relationships in securing jobs after graduation). Funding by the home country employer would be a strong incentive for a U.S. employer to take on a graduate for a limited period of time. 
they did not speak with that person before accepting an offer of admission..$^{57}$

Of course, there obviously are other reasons students apply to particular schools, including mundane issues such as the weather and more relevant concerns such as the relation of a school's location to the international economy. For some students, the availability of interesting opportunities for a spouse is important. In addition, there appears to be some correlation between the number of applications and the tenure of the graduate director of a law school. ${ }^{58}$

\section{B. The Bar Exam}

One reason that foreign law graduates attend U.S. graduate law programs is that it qualifies them to sit for the bar exam in certain U.S. jurisdictions. ${ }^{59}$ Table 6 reveals the variety of perceptions among the graduate directors of the thirty-five schools that reported detailed information regarding the number of foreign graduate students taking a U.S. bar examination. ${ }^{60}$

57 Int. 8.

58 For the thirty-five law schools that responded to the survey, the relationship of applications to enrolled students ranges from four percent to sixty-three percent. For schools with more than twenty enrolled students, the average school enrolled twenty-three percent of the number of applications they received for the 2003-04 school year. Schools in California attract significant numbers of applicants. Outside of California, the tenure of the program director appears to have some correlation to the rate of applications to the program. For the schools with programs of more than twenty students, seven schools outside of California enroll fewer than twenty percent of their applicants. Program directors at six of the seven schools have been in their positions for more than five years.

59 Notwithstanding this goal of LL.M. students, U.S. law schools typically are reluctant to guarantee that the LL.M. will satisfy the conditions for sitting for a bar examination. See, e.g., Yale University School of Law LL.M. program, available at http://www.law.yale. edu/outside/html/Admissions/admis-llmfaq.htm (last visited Mar. 14, 2005) ("The LL.M. degree from Yale Law School makes one eligible to take the bar exam in some states, but it does not prepare you for it.") But see NYU School of Law, available at http://www.law. nyu.edu/depts/admissions/info/graduate/index.html (last visited Oct. 5, 2005) ("Successful completion of an LL.M. degree qualifies foreign attorneys to take the New York Bar examination.").

60 Schools interpret bar requirements differently. Compare the approach of Washington \& Lee University School of Law, available at http://law.wlu.edu/admissions/FAQs.asp (visited Mar. 14, 2005) ("Consistent with the approach taken by other United States law schools, our policy is not to certify that our students who have completed only the one-year LL.M. program are qualified to seek admission to the bar of any state. For this reason, in most cases, a person holding an LL.M. in United States Law will not be eligible to receive a license to practice law in most United States jurisdictions. An exception applies in the case of admission to the bar of the state of New York, which allows applicants to take the New York bar examination upon verification of successful completion of the LL.M. degree; in 
Table 6: Percentage of 2003 Graduates Who Took a Bar EXamination in a U.S. Jurisdiction, as Estimated by Directors of Graduate Programs

Number of Schools

1

2

4

8

4

4

3
Percentage

$$
\begin{array}{r}
70 \% \\
50 \% \\
40-45 \% \\
30-35 \% \\
20-25 \% \\
10-15 \%
\end{array}
$$

0

Graduate directors indicated that most of those graduates who plan to take a U.S. bar exam intend to take the exam in New York. Thirty of the thirty-five schools reported that 2003 graduates took the bar in New York. New York's regulation of foreign law graduates is liberal and straightforward, and permits most foreign law graduates to qualify to sit for the bar examination after completing a one-year graduate degree law program. ${ }^{61}$ Nineteen of the thirtyfive schools reported that graduates also took the California bar, and twelve schools reported that graduates sat for the bar in one or two additional U.S. jurisdictions that were either the jurisdictions in which the law schools were located, or jurisdictions in the same region where the law school was located. ${ }^{62}$

While many foreign law graduates want to take a U.S. bar exam, restrictive bar rules frustrate their intentions in certain U.S. jurisdictions, even though these same jurisdictions are home to law

other words, New York does not require the school to certify that the applicant is qualified to seek admission to the bar") and Indiana University School of Law -Indianapolis last visited http://indylaw.indiana.edu/llm/faq.htm (visited Mar. 14, 2005) ("There are 10 states that permit international LL.M. graduates to take their bar examination. Many of these states have additional requirements that may preclude an LL.M. graduate from taking the bar. . . . The ten states that allow foreign LL.M. graduates to take their bar examination are: Arizona, California, Connecticut, Michigan, New Hampshire, New York, North Carolina, Rhode Island, Tennessee, and Virginia.").

61 For analysis of the bar rules in U.S. jurisdictions as applied to foreign lawyers and law graduates, see Carole Silver, Carole Silver, Regulatory Mismatch in the International Market for Legal Services, 23 J. INT'L L. \& Bus. 487 (2003). See generally, ABA Section of Legal Education and Admission to the Bar and National Conference of Bar Examiners, Comprehensive Guide to Bar Admission Requirements 2005, available at http://www. abanet.org/legaled/publications/compguide2005/compguide2005.html (last visited Oct. 5, 2005).

62 These jurisdictions are not identified because doing so may reveal the identity of the schools that responded to the survey. 
schools with programs for foreign law graduates. ${ }^{63}$ Inability to sit for the bar exam in a particular jurisdiction is an enormous roadblock. According to one LL.M. graduate, the issue of the bar exam ... keeps coming up again, again and again. You know it's a huge issue because the U.S. is extremely attractive for people to work in. The labor market is very, very fluid in everything but law, it seems. It's very difficult actually getting here and getting practicing and then actually get a job. Because a lot of the big law firms won't look at you unless you're going to get qualified, understandably so. And so, I find a lot of the states are really kind of difficult still. ${ }^{64}$

In the competition among U.S. law schools for transnational graduate students, it appears that location as it relates to bar admission rules matters. Schools located in New York are disproportionately successful in placing their graduates in jobs in New York, ${ }^{65}$ and New York's international role as a financial center likely leads to more jobs for transnational lawyers than elsewhere in the U.S. Bar admission rules seem to matter, at least indirectly, in the competition for foreign law graduates.

\section{Experiences in U.S. Law Programs}

The experience of foreign law graduates in U.S. graduate law programs may be substantially different depending upon the U.S. law school they attend, and differences in experiences may translate into differences in the programs' value. In large part, this is attributable to the ways in which alumni use the networks they develop during their year in the U.S. It remains unclear, however, whether students at more prestigious schools have more valuable connections because of their law school classmates, and if so, whether this increase in value corresponds to greater career opportunities. Perhaps the more prestigious law schools attract students who have stronger social and professional networks at the outset.

63 See Silver, supra note 61 , for a discussion of the regulation of bar admission for foreign lawyers and law graduates.

64 Int. 15 (December 2003). Another lawyer working in the U.S, a 1990 graduate of a U.S. LL.M. program who practiced in California for several years before moving to Illinois, also described his frustration with the restrictive bar rules in Illinois: "I had to work intensely with another person in the firm, because I was not admitted to the bar. I had to have everything reviewed by an admitted attorney. It was ridiculous." Int. 20.

65 See Carole Silver, The Case of the Foreign Lawyer: Internationalizing the U.S. Legal Profession, 25 FoRdHAM J. INT'L LAw 1039-84 (2002) (discussing the unusually high proportion of Fordham foreign graduate alumni working in New York). 
Alternatively, a small graduate program may result in closer connections among students that may offset, to some extent, the advantages of the larger and more prestigious programs.

\section{(i) Academic Experiences}

In order to gain insight into the academic interests of graduate students, I asked the graduate directors at the thirty-five surveyed schools about students' course selections. Aside from particular required courses, graduate students at the thirty-five schools focused primarily on courses in U.S. law related to business issues, including corporations, securities regulation, and mergers and acquisitions. Other important areas of study mentioned by the graduate directors at these schools were international law, intellectual property, and negotiations or alternative dispute resolution, but the graduate directors stressed that these areas of study were clearly secondary to the business-related courses. Finally, half of the thirty-five schools reported that their graduate students had an opportunity to participate in a journal, either by publishing in the journal or through a board position, or both.

\section{(ii) Interaction with Other Students}

Many graduate students expressed frustration with the difficulty of developing strong ties to their J.D. classmates. One commented that "[i]t's hard to get into the American J.D. group. Because they ... . don't have a lot of interaction among themselves either, .... in the sense of social events, they stay very superficial among each other. . ." 66 Another explained that her J.D. friends were "transfer students who also felt excluded."67 Others attributed their lack of friendships with J.D. students to their own challenges. For example, one student explained, "I wish I knew J.D.s better. My English is not good, and I worry about disturbing others in speaking . . .."

The relationship between graduate and J.D. students is an issue to which directors of graduate programs are attuned, and they attempt to integrate the two groups in various ways. Many schools match J.D. and foreign graduate students in an advisor, mentoring or buddy relationship. J.D. advisors might be asked to review the

66 Int. 3 (November 2003).

67 Int. 11 (November 2003). During law school, this individual had a J.D. mentor who was a transfer student.

68 Int. 5 (November 2003). 
resumes of their graduate advisees, offer opinions on course selection and other school-related issues, help students with English, and participate in social events for the graduate students. At one school, J.D.s are paid to edit the theses of international students.

While relationships between graduate and J.D. students may be frustrating, graduate students described strong and rewarding relationships with their graduate program classmates. One graduate used his LL.M. colleagues as sources of information when he decided to move from his job in his home country to a position in New York. He "just called everybody to get every tidbit of information that could be useful." 69 This same individual recently organized a ten-year reunion for his LL.M. class, attended by more than fifty alumni. Another graduate explained that " $[t]$ he LL.M. students played a big role in the experience being worthwhile ... A large percentage of ... what ... was useful and enjoyable was my classmates. I made friends [and] potential partners."70

The efforts of graduate directors to involve foreign students in the life of their law schools and legal communities offer myriad opportunities for LL.M. students to establish strong bonds. Graduate students offer lectures on their fields of interest at one school and on their home country's legal profession at several schools. One school hosts a regular colloquium on legal practice for graduate students; several have their faculty speak to graduate students about their areas of expertise or substantive areas of law in which they teach. At another school, graduate students with teaching experience offer courses in their native language in the context of legal studies; students at this school also organize and participate in language tables. One school holds weekly meetings for small groups of invited international students (LL.M. and exchange students) to allow students to get to know each other and to consult about problems or concerns. Activities run the gamut from holiday parties to tours of local points of interest, athletic activities, country-theme dinners; visits to courts and other legal institutions are common as well. One school even runs a winter driving seminar for their graduate students, and another offers an LL.M. film series that is open to the law school community. While these activities offer ample opportunities for graduate students to establish strong relationships with one another, they do not necessarily succeed in

69 Int. 17 (December 2003).

70 Int. 9. 
drawing graduate students closer to J.D. students. Graduate students understand the importance of networking with their J.D. classmates, but it is not clear that J.D. students have a similar understanding. The message for J.D. students may need to come from elsewhere in the law school.

\section{(iii) Working in the U.S. and Beyond}

Many foreign law graduates who enroll in U.S. graduate programs would like to work in the U.S. after graduation. Of the thirty-five schools providing detailed information, twenty-five graduate directors estimated the number of their graduates who looked for work in the U.S. Nearly fifty percent of these directors estimated that seventy-five to eighty percent of their students would like to stay in the U.S. to work for some period following their graduation. ${ }^{11}$

LL.M. graduates want a U.S. law firm experience to enhance their U.S. legal education, to earn the high salaries paid in the U.S. to lawyers, and to see how U.S. law is practiced. Some look for work in the U.S. for personal reasons - as one LL.M. graduate explained, "I met a girl."72 Others find themselves caught up in the competition and momentum of their peers in looking for jobs. A 1999 graduate described his decision to look for work in the U.S. as related to his sense of competition with his classmates. "[A]ll these people . . . all the LL.M.[s] . . . were getting jobs and I didn't, so it was kind of challenging myself, saying why didn't I get a job? . . . [A]ll of these guys were talking all the time . . .about how important it was to continue your education in a law firm here."73 Another graduate described her interest in finding a job in the U.S. as being sparked by the workshops sponsored by the Career Center: "[S]ince we got here, we didn't think we would stay here; . . . it was just something that evolved from all these meetings with [the] $\mathrm{Ca}$ reer Center. And . . . all the other LL.M.s were looking for a job. So, eventually you start looking."74 Another shared this sentiment, describing his U.S. law school as,

71 Twelve percent of the graduate directors estimated that ninety percent of their graduates wanted to work in the U.S., and sixteen percent reported that fifty percent of their graduates wanted to work in the U.S. following graduation.

72 Int. 15.

73 Int. 8 (June 2000).

74 Int. 6. 
very employment oriented; . . . without even expecting it I got involved in things with the placement office and interviewing, and I thought it was a pleasant experience, and I started thinking, well, why not get even more exposure, a few more months, and things like that. And for some reason, I just started getting into the goal of employment, without even knowing why and how; it just sounded more and more interesting. ${ }^{75}$

An additional issue is how foreign law graduates find work in the U.S. In fact, they do everything that J.D. students do and more. Over forty percent of the thirty-five schools responding with detailed information do not permit their graduate students to participate in on-campus interviews. The justification offered for this difference in treatment is that U.S. law firms are generally less interested in hiring LL.M. graduates than J.D. graduates, and schools are reluctant to allow LL.M.s the precious interview slots if there is little likelihood that interviewers will hire from the LL.M. pool. This attitude is shared even at schools where graduate students do participate in on-campus interviews. At one such school, the graduate director commented that graduate students "don't get hired through on-campus interviews."

Directors of graduate programs emphasize the importance of home-country contacts when discussing how graduates find jobs in the U.S. Most graduate directors consider those home country contacts crucial. Several schools write to admitted students before they arrive in the U.S., asking them to begin thinking about who might help them find opportunities in the U.S. According to one graduate director,

[G]rades are not important at all for finding work in the U.S. Timing is off regarding looking for a job in the U.S. They'd be hired because of what they bring to the table with foreign contacts and language skills. Firms look at grades, but no big deal if the grades are not stellar. ${ }^{76}$

Another director reported,

Grades matter some, but usually other factors weigh in. The identity of the home country matters, language ability and which languages the student speaks matters. If the student does really great in grades, this helps. ... How they do academically in the LL.M. program is important, but not determinative. . . . They are looking at background, what they've done in the past, and

75 Int. 10.

76 Int/survey $\mathrm{A}$. 
they take their admission into [this law school] as evidence of their academic ability. ${ }^{77}$

An experienced graduate program director commented that what ". . . matters in securing jobs is first, whether a firm has business operations in a particular country; second, whether a student is from a common law country; third, whether the student has had prior practicing experience with a major law firm; and finally, the personal characteristics of the student."78 Yet another graduate director advised that "[t]o get hired as a permanent associate in the U.S., the student generally must come from a common law country. Occasionally, a German student also will find a permanent position as an associate." 79 The explanation offered for the success of German students is their high proficiency in English.

LL.M. graduates' stories about finding work do not necessarily support the perceptions of the graduate directors. While personal connections helped some graduates find work, others secured positions without such connections, either through one of the job fairs for foreign law graduates, letter-writing campaigns or even Internet postings. More representative data and analysis is needed. ${ }^{80}$

\section{Conclusion}

In the market for graduate legal education, challenges are being waged to the leading position of U.S. law schools. Changes brought by the economic downturn of the early 2000 s combined with post-9/11 attitudes towards immigration are negatively affecting the ability of U.S. law schools to attract increasing applicants to their graduate programs. In addition, the high tuition charged by U.S. law schools is now being met by less expensive alternatives offered by European and Australian universities. The inability of many U.S. law school graduate program alumni to secure employment in the U.S. also impacts the competitiveness of the programs, since applicants may be wary of incurring significant debt for tuition without the hope of obtaining a job - in the U.S. or elsewhere that would help recoup their investment. Moreover, the growth in

77 Int/survey B.

$78 \mathrm{Int} /$ survey $\mathrm{C}$.

79 Int/survey D. See Silver, The Case of the Foreign Lawyer: Internationalizing the U.S. Legal Profession, 25 Fordham J. OF INT'L L. 1039, 1045 (2002) for a discussion of the apparent advantage of foreign law graduates from common law countries compared to law graduates from civil law countries.

80 The subject is the focus of my project, Careers of International Lawyers. 
the size and number of U.S. graduate programs has rendered the graduate experience more common, which in turn reduces the value of the degree as a distinguishing credential.

As a result, the stakes have been raised to capture distinction beyond the LL.M. For some, passing a U.S. bar exam is sufficient; for others, the experience of working in a U.S. law office offers additional capital. These credentials are ancillary to the offerings typical of U.S. graduate programs for foreign law graduates. Indeed, the schools have not uniformly endorsed efforts by their foreign graduate students to accomplish these goals. The ambivalence expressed by U.S. law schools toward bar passage and employment in the U.S. is understandable from the schools' perspective, because the most significant audience for U.S. law schools consists of J.D. students, applicants and graduates. The J.D. group outnumbers the LL.M. group, and more important, they are more significant for purposes of financial support and reputation, since the J.D. program serves as the basis of the ranking information that has assumed such importance in law school recruiting. Moreover, concerns over bar eligibility for foreign law graduates raises concerns that the ABA Section of Legal Education and Admission to the Bar or state bar authorities, or both, might take steps to regulate U.S. law graduate programs and tighten regulations against rights of practice by foreign lawyers and law graduates. At the same time, law schools are conflicted by the prospect of their foreign graduate students' employment in the U.S. because the focus of their placement efforts is on J.D. graduates, the primary product of U.S. law schools. Schools may fear that an endorsement of foreign graduate students would impinge on the market for J.D. graduates.

Of course, as long as U.S. business and law remains internationally significant, U.S. law schools will remain attractive. The challenges discussed above will impact certain U.S. law schools more than others. Elite U.S. law schools most likely will not suffer much from increased competition for foreign law graduate students. A Harvard degree may not afford greater opportunities for passing a U.S. bar exam but it continues to open doors around the world. For the vast majority of U.S. law schools that do not occupy an equally elite status, however, there may be more pressure to change in response to the challenges discussed above. Change, for example, might come in the form of adapting to the more restrictive immigration environment by relocating foreign graduate programs offshore. Several schools recently have created graduate 
programs based primarily or entirely in another country in order to attract increasing numbers of students and avoid at least some of the immigration restrictions. ${ }^{81}$ Foreign-based graduate programs generally are aimed at students who otherwise might not enroll in a U.S.-based program, either because of limited resources or professional or other commitments that prevent them from a year-long leave. Certain schools have discovered that their J.D. population is internationalizing, both as a result of more foreign applicants who may not necessarily have legal training in their home countries and at certain schools because of a willingness to grant one year's credit towards the J.D. degree for foreign legal education. Still other schools might support the efforts of their foreign graduate students to further distinguish themselves by passing the bar or finding work in the U.S., or both.

The response of U.S. law schools to increasing competition for educating international lawyers continues to unfold. The tuition dollars at stake are significant, but equally important is the need to internationalize the student bodies of U.S. law schools so that J.D. students have an opportunity to become acquainted with foreign legal systems and lawyers through their daily interaction with graduate students in and out of class. If the schools cannot compete effectively with foreign schools for students interested in graduate legal education, U.S. J.D. students will lose the opportunity to join the global legal community while still in law school.

Globalization tends to increase existing divisions within markets as it intensifies competition. The market for legal education is no exception. In order to attract foreign law graduates to their graduate programs, U.S. law schools must vie for position both domestically and internationally. In these efforts, they are restricted and supported by regulation and market conditions unique to the

81 Temple University Beasley School of Law offers graduate programs in China and Japan; see http://www.law.temple.edu/servlet/RetrievePage?site=TempleLaw\&page=International_Students (last visited Oct. 12, 2005). The University of Minnesota Law School is planning to begin a new LL.M. program housed at and in partnership with China University of Political Science and Law; see http://www1.umn.edu/umnnews/Feature_Stories/Carlson_School_program_rated_number_one_in_China.html (last visited Oct. 12, 2005). Northwestern University School of Law offers an LL.M. program in Seoul and is in discussions regarding additional programs; see http://www.law.northwestern.edu/graduate/ llmexec/ (last visited October 12, 2005). New York University recently announced a dual degree graduate program with National University of Singapore; see NYU@NUS: Dual LL.M. degree programme for the global-minded, (2/15/06), at http://newshub.nus.edu.sg/ headlines/0602/nyu_15feb06.htm (last visited Mar. 17, 2006). 
U.S. and even to their state jurisdictions, including the international-ness of their locations, regulation of foreign law graduates' rights of practice, and the size and breadth of the legal market in their jurisdiction. Law schools may attempt to position themselves as national rather than tied to one particular U.S. location in hopes of attracting the attention of foreign law graduates who may not understand the nuances of the U.S. legal market. Just as law firms have re-created themselves in order to enhance their international character, so U.S. law schools may well follow suit in the pursuit of international students and reputation. 
